\title{
BUDAYA STATECRAFT DI INDONESIA
}

\author{
R. Bambang Soediadi Adi Purwanto \\ e-mail: godzieplyahoo.com
}

\begin{abstract}
ABSTRAK
Budaya statecraft adalah suatu tata-kelola pemerintahan sesuai dengan kebiasaan dan pola perilaku masyarakat dalam membangun relasi sosialnya. Prinsip relasi sosial tersebut adalah bagaimana memilah in-group atau out-group suatu jabatan secara hierarkhis. Relasi tersebut biasanya berdasarkan ikatan kerabat atau sejenisnya. Hal itu menjadi semacam parameter dalam mengikat individu kedalam kelompok karena dipandang mampu menangani keadaan atas dasar kepercayaan. Bagi Lewellen, keadaan itu adalah cara membangun suatu budaya berkelompok, like brotherhood; katanya. Tujuannya tentu saja menjaga integritas berkelompok dan harmonis.
\end{abstract}

Kata Kunci: statecraft, tata-kelola pemerintahan.

\section{ABSTRACT}

Statecraft, is the art or practices of conducting affairs of state (governance). Culture is collective phenomenon or it can be said is the collective programming of the mind. Therefore, statecraft culture is art of practices on conducting affairs based on programming mind. Group sodality in collective craft is how some people create the group of practices to do so, in order to maintain the integrity of the group on harmony.

Keywords: statecraft, governance.

\section{PENDAHULUAN}

DiKotaJakarta,terdapat sejumlah 88 buah lembaga non-struktural, 34 kementerian, serta 28 lembaga nonkementerian (Kompas, 18 Juli 2011). Jumlah tersebut masih ditambahkan lagi dengan sejumlah tim dan satuan tugas, guna menangani hal-hal yang bersifat ad-hoc. Tentu saja, jumlah tersebut kini telah berubah, dalam rangka efisiensi sejalan dengan kebutuhan. Keberadaan lembagalembaga tersebut_baik lembaga negara, lembaga politik, maupun lembagapemerintahan — padadasarnya adalah membantu lembaga di atasnya, agar melancarkan segenap tugas dan fungsi lembaga, sesuai dengan kapasitas masing-masing. 
Oleh karena itu, para "pembantu" tersebut lebih banyak melakukan tugasnya, karena hal itu sesungguhnya adalahtanggung-jawabatasan.Namun, atasantampaknyatelahmendelegasikan kewenangannyaatasdasarkepercayaan dengan mengat asnamakannya. Bentuk paling mudah adalah tanda paraf pada setiap tanda tangan yang menyatakan bahwa tanda paraf tersebut telah melalui sebuah proses verifikasi dan segenap tanggung-jawab atas segala kemungkinan beradaditangan pemaraf itu. Andaikata saja sebuah kebaikan yang didapatkan, maka hal itu adalah sepenuhnya hak para atasan. Akan tetapi, andaikata saja yang terjadi adalah sebaliknya, maka hal tersebut adalah tanggung-jawab bawahan.

Pemilihan seorang bawahan sebagai orang yang kelak akan dipercaya guna mengemban tugas tersebut, sangat unik, karena biasanya tidak berkaitan dengan hal-hal seperti diumpamakan sebagai kata-kata what are you, tetapi justru who are you. Prinsip pertama, menanyakan persoalan kemampuan seseorang dan tidak memedulikan siapakah mereka. Sementara itu, di dalam prinsip kedua terdapat keadaan mempertanyakan terdapat hubungan apakah dengan relasi seseorang tersebut. Prinsip kepercayaan itu hanya melihat relasi yang kelak akan dibangun oleh pembantu tersebut, kelak.

\section{TINJAUAN PUSTAKA}

Biasanya, relasi dibangun berdasarkan suatu ikatan yang dikenal dengan prinsip "Sodality is simply a formal or informal association, such as a family group, a college fraternity, or the boy scouts (Lewellen, 1983:25). Artinya, di dalam prinsip berelasi tersebut didasarkan pada suatu ikatan sosial yang bersifat kekeluargaan atau semacamnya. Adapun relasi tersebut, tampaknya lebih banyak mendasarkan pada ikatan emosi kekeluargaan atau seolah keluarga, sehingga lebih banyak menekankan, bahwasanya ikatan itu adalah yang utama, daripada mengutamakan kemampuannya. Tentu saja, keadaan tersebut tak terbangun sekejap, akan tetapi melalui rentang waktu relatif lama, maka ikatan emosional itu menjadi satu-satunya tali ikatan yang menguatkan dan dianggap sebagai sebuah kepercayaan. Kepercayaan tersebut adalah semacam jaminan bahwasanya kenyamanan pemberi otoritas dapat dan mampu berjalan sesuai dengan rencana dan keinginan serta terlaksana dengan baik.

Prinsip relasi (hubungan) sosial demikian itu dipandang terbaik mengingat bahwa, relatif, hanya merekalah satu-sat unya relasi di antara mereka dan dapat dipercaya. Secara sosiologis, hal itu berarti mempunyai pengertian sebagai kelompok in-group dan di luar keadaan tersebut adalah kelompok out-group, dan oleh karena itu out-group dianggap tak layak 
dipercaya. Hakikatnya, membangun budaya kerja, bersama-sama dengan out-group dipandang tidak kredibel.

Kesulitan dalam membangun budaya kerja dalam penyelenggaraan pemerintahan (governance) ataudalam hal ini adalah budaya statecraft sesungguhnya harus dipahami sebagai sebuah cara mengamankan pranata sosial agar tidak goyah atau terganggu keberadaannya. Pranata sosial tersebut tent unya dapat eksis bila diisi oleh para pengurusnya atau berisikan orangorang dengan kategori sosial homogen. Kehomogenan itu sebagai jaminan rasa aman bagi siapa pun, agar setiap tindakan atau putusan lebih mudah dipecahkan dan diselesaikan oleh anggota-anggota yang homogen. Oleh karena itu, keheterogenan atau outgroup dipandang berpotensi dapat mengganggu keberadaan kelompok atau menggoyahkan kelompok secara umum. Statecraft akhirnya dibangun oleh anggota-anggota yang berasal, idealnya tentu, dari kelompok yang homogen. Tujuannya, lebih cenderung agar keberadaan kelompok dapat terjaga kelangsungannya dan bahkan tampaknya, hanya dengan cara itulah kelompok dapat eksis. Kelompok outgroup berarti berpotensi untuk mengambil resiko tinggi dan hal itu layak dihindarkan.

Perbedaan di dalam sebuah kelompok, bagaimana pun dimungkinkan, karena meskipun sehomogen apa pun sebuah kelompok, sebenarnya berpotensi pula memunculkan perbedaan. Persoalannya, pemahaman bahwa kelompok dengan keanggotaan yang homogen adalah upaya mengecilkan potensi konflik. Artinya, perbedaan harus dikecilkan agar dampaknya dibatasi atau dikurangi sesuai dengan tingkat perbedaannya atau degree of differentiate di dalam kelompok.

Oleh karena itu, sebuah kelompok dibangun dengan cara, terutama, melalui saluran-saluran layaknya seperti family association atau fraternity. Adapun saluran-saluran itu dianggap dapat meredam atau mengecilkan tingkat perbedaan umumnya. Perbedaan dan pembeda di antara anggota-anggota kelompok tentu akan terbangun seiring waktu. Perbedaan tersebut diperlukan guna dijadikan semacam stratifikasi sosial secara sederhana agar tak tertukar, melalui sejumlah atribut. Atributatribut tersebut akan mencirikan siapakah mereka dan siapakah kami, dan dengan demikian tat a cara berelasi di antara mereka seolah terstruktur. Struktur tersebut akan menguatkan wibawa sebuah jabatan pemerintahan misalnya, sehingga dianggap dapat mengokohkan apa pun yang diemban, baik secara kuantitas maupun kualitasnya.

Keadaan tersebut berlangsung agar tidak terjadi sesuatu yang dapat mengganggu dan tak terbantahkan dan siapa pun mengetahui bahwa demikianlah adanya serta tidak terjadi konflik kepentingan akibat kekeliruan. 
Perbedaan atribut memang seolah membentuk budaya tertentu dan demikian rupa agar jelas siapakah seseorang, cukup dengan mengetahui atribut-atributnya. Tingkat perbedaan tersebut, biasanya berdasarkan ukuranukuran tertentu yang menunjukkan derajatnya. Major means of social integration based on kinship, voluntary associations and/or age-grade (Lewellen, 1983:20-21). Derajat perbedaan adalah ukuran dalam membangun social of integration berkelompok dan dengan demikian otoritas atas-bawah jelas, sehingga konflik relatifterhindarkan. Tujuannya dapat dianggap sebagai upaya membangun keharmonisan di dalam berkelompok, serta menjaga kredibilitas atasan. Atasan tak layak mendapat malu karena hal itu akan mengganggu atribut terpasang. Sementara itu, bawahan bertugas sesuaidenganotoritas atasanmengecek segenap hal yang berkaitan dengan atribut atasan agar segalanya berjalan sesuai dengan rencana dan berjalan lancar.Bilamanaterjadiketidakberesan, apa pun bentuknya, maka bawahan akan berusaha melindungi atasan serta menjadikannya seolah hal itu adalah tanggung-jawabnya. Dalam hal ini atasan menjadi semacam patron bagi bawahannya dan mereka tampil seolah tak tersentuhkan dengan membangun sebanyak mungkin bawahan. Para bawahan sepenuhnya akan mendukung atasan, mengingat otoritas mereka sesungguhnya hanyalah perpanjangan atasan semata.
Bawahan, karenanya, menjadi perpanjangan otoritas atasan sesuai dengan fitrah mereka. Artinya, otoritas mereka sepadan dengan degree of differentiate jabatannya, sehingga kapasitas mereka amat berkaitan dengan fitrahnya. Fitrah tersebut adalah semacam batasan power mereka, tercermin melalui lembaga yang dibawahkannya. Semakin besar power yang dimiliki, maka hal itu akan menunjukkan seberapa besar pula fitrah yang disematnya. Tidak heran bila para atasan pun memiliki sejumlah power dengan tampilan luar, berbentuk sejumlah jabatan semu agar terlihat seberapa besarkah fitrah yang dimilikinya. Bawahan, akhirnya seolah tak memiliki otoritasnya secara independen, karena mereka sebenarnya adalah bagian yang terintegrasi secara utuh dari otoritas atasannya, yang tak terpisahkandantakmemungkinkannya untuk bekerja secara independen. Mereka hanyalah turut-serta di dalam bagian otoritas atasan dan karena itu otoritas mereka sangat dibatasi, misalnya hal itu tampil dalam bentuk tanda paraf mereka.

\section{PERMASALAHAN \\ DAN PEMBAHASAN}

Budayastatecraftdapat dijabarkan sebagai suatu pola perilaku masyarakat didalam membangun relasi sebuah kelompok sosial, berdasarkan prinsip in-group-out-group. Adapun ukuran tersebut adalah seperti disodorkan oleh 
Lewellen, yaitu ikatan kerabat atau sejenisnya. Oleh karena itu, ukuran ingroup adalah ikatan kerabat atau semacamnya, dan di luar hal itu dapat dianggap out-group. Prinsip tersebut tampaknya dijadikan ukuran dalam membangun relasi sosialnya dan diharapkan mampu menguatkannya. Hal itu dapat dianggap sebagai cara atau strategi membangun budaya ikatan berkelompok dalam berpemerintahan agar ajeg dan harmonis.

Ikatan sebuah kelompok, dalam usulan Lewellen, disebut sebagai sodality atau companionship at au juga association, dan oleh karena itu, berisi sejumlah individu dalam kelompok family groups. Kelompok-kelompok dalam kategori tersebut adalah suatu ikatan berdasarkan pertalian darah atau seolah seperti pertalian darah atau semacamnya, like brotherhood, karena dengan cara tersebut, dipandang mampu menguatkan in-groupnya. Artinya, keanggotaan di dalam sebuah kelompok akan lebih ajeg bila setiap anggota memiliki ikatan darah pula atau sejenis dan dengan demikian alur otoritas atas-bawah harmonis sesuai dengan otoritas masing-masing. Hal seperti itu, sebagai salah-satunya, berdampakpadamenguatnyahubungan pemerintahan antara pemerintah dan yang-diperintah bagaikan sistem pemerintahan-kekerabatan (statecraft governance).

Otoritas setiap anggota kelompok memiliki labelnya sendiri dalam bentukatribut-atribut.Atribut tersebut mencirikan siapakah pemegang otoritas masing-masing. Adapun masing-masing pemegang otoritas tersebut dibedakan berdasarkan degree of differentiate, sesuai dengan kapasitasnya. Kapasitas setiap tingkatan akan membedakan kualitas dan kuantitasnya. Atribut tersebut secara kasat-mata memudahkan pemegang otoritas agar siapa pun tidak keliru dengan siapakah ia berhadapan dan bagaimanakah penghormat an yang pantas seharusnya dilakukan, baik terhadap dirinya maupun terhadap at asanataubawahannya.Penghormatan itu adalah fitrah yang harus dipenuhi, sesuai dengan jenjang misalnya. Penjenjangan tersebut berdasarkan ukuran-ukuran tertentu, yang demikian rupa mudah dikenali melalui atributatribut terpasang.

Budaya memberikan tempatnya, tentang bagaimanakah suatu keadaan atau kebiasaan diteruskan dari satu generasi ke generasi selanjutnya. Artinya, hak dan kewajiban seseorang dengan atributnya akan ditradisikan, sesuai dengan kebutuhan. Lembagalembaga formal semacam tersebut di awal, mungkin saja fenomena tersebut. Banyak pula lembaga tersebut sifatnya tumpang tindih satu dengan lainnya. Dalam kaitan ini, lembagayang banyak jumlahnya menampilkan power yang dimiliki tiap lembaga tersebut. Hak atasan seolah tanpa batas dengan sedikit kewajiban, karenakehadirannya telah terwakilkan melalui atributnya. Selain itu, masih terdapat "tambahan" atribut yang menunjukkan 
keberadaannya dengan jumlah yang luar biasa dalam bentuk penghargaan yang diterimakan.

Atribut lainnya masih dianggap diperlukan guna mengokohkan power itu agar fitrahnya sebagai atasan misalnya, tampak semakin ajeg. Sebagai sebuah simbol, berbagai atribut tersebut akan mencerminkan simbol-simbolnya. Semakin banyak, maka hal itu akan menunjukkan hakikat power yang dimilikinya. Oleh karena itu, seseorang dengan satu jabatan saja, dirasakan kurang terlihat kokoh dan sekian saja fitrahnya. Keadaan itu tidak berhubungan secara fungsional dengan berbagai peran yang tersemat di dalam dirinya, mengingat semuanyatelahterwakilkan oleh sejumlah "pembantunya" dan karena itu sebenarnya merekalah yang paling sibuk dalam menjamin keberadaan atasannya.

Selain itu, setiap pembantu akan mendapat kan turunan fitrah dari atasan sesuai dengan bobot masing-masing. Fungsi mereka paling jelas dan nyata keberadaannya mengingat kewajibannya. Atasan lebih banyak mengambil peran tak terlalu banyak, dan bahkan lebih banyak bersifat seremonial saja. Oleh karena itu, dapat dikatakan bahwa, semakin banyak para pembantu, akan mengokohkan power mereka, dan sekaligus membantunya menjadikan mereka jugasemacambarrierbagikenyamanan otoritasnya tersebut. Barrier tersebut pun muncul pula didalam gelar yang tersemat. Gelar tersebut menunjukkan status sosialnya. Semakin tinggi dan banyak gelar yang dimiliki maka akan semakin menunjukkan degree of differentiate berdasarkan gelar dan peran yang dipegang. Oleh karena itu, tak mungkin kedudukan seseorang tertukar karena telah tersemat gelarnya tersebut sebagai atribut jabatannya. Selain itu, gelar tersebut pun menunjukkan fitrah yang disematkan oleh "atasan" mereka ketika selesai bersekolah. Terlebih lagi, bilamana seseorang mendapatkan gelar profesor, apapun wujudnya, apakah honoris causa atau biasa meskipun mereka tidak berkecimpung di dunia pendidikan, maka hal itu akan meninggikan derajat pemangku gelar tersebut. Karenanya, orang bergelar satu tidak akan melampaui derajat orang yang bergelar dua buah. Gelargelar tersebut adalah atribut yang menetapkan di sanalah tempatnya dan hal itu dapat dikatakan sebagai proper place yang sesuai dengan social conventions. Adapun properplace atau tempat yang sesuai bagi para pembantu tersebut berdasarkan atribut-atribut yang terpasang dan hal tersebut adalah sesuai dengan fitrahnya agar jelas di manakah seharusnya berada.

Secara sederhana, faktanya adalah bahwa sebuah pekerjaan hampir selalu dilaksanakan oleh 4-5 orang pegawai dengan stat us yang sederajat. Misalnya pekerjaan membuat surat resmi; yaitu proses pertama dibuat oleh seorang bawahan, dan hanya membuat. Kemudian berkas surat tersebut 
diserahkan ke atasannya agar diparaf. Selesai bagian ini, kemudian oleh atasannya lagi, ditandatangani. Oleh orang yang berbeda, dengan status yang sama, diberi nomor surat dan dicap lembaga, kemudian didisposisikan dan dikirimkan. Seharusnya, pekerjaan tersebut cukup satu orang saja. Bahkan, kini lima atau empat pekerjaan dapat dilakukan oleh satu orang saja, dan selesai.

\section{Statecraft Governance}

Khusus dalam konteks tata-kelola pemerintahan atau penyelenggaraan pemerintahan (governance) $\mathrm{di}$ Indonesia, budaya statecraft juga terjadi. Budaya statecraft governance ini melanda hampir di setiap jenjang/ tingkat, lapangan, dan urusan pemerintahan yang sudah sejak lama berlangsung.

Di tingkat desa, tradisi turuntemurun keluarga kepala desa_-atau dengan sebutan lain di lain wilayah/ daerah/suku—banyak terjadi, baik secara langsung atau tidak langsung karena terselang oleh kepala desa dari keluarga lain. Hal ini terjadi mungkin saja karena kepuasan masyarakat di desa atas keberhasilan atau kinerja, karisma, atau ketokohan pemerintahan kepala desa (orang tua, kakek, dan seterusnya ke atas) sebelumnya. Ini positif. Yang negatif adalah apabila keberlanjutan 'trah' kepala desa itu terjadi karena ikatan-emosional yangdiperintah terhadap yang-memerintah, dan/atau secara sebaliknya, atas dasar budaya statecraft yang tidak patut dan pantas, seperti karena kekerabatan, persekongkolan, atau yang lainnya. Hal yang terakhir inilah yang bisa jadi yang mendorong konflik sosial antarkeluarga besar, antarkampung, antarsubsuku, dan/atau antarelit desa. Hal ini bisa jadi semakin panas ketika beberapa perangkat desa yang diangkatnya atas dasar 'bedol keluarga', 'bedol kerabat', atau 'bedol kroni'.

Isu dan fenomena statecraftgovernance itu kini menjadi menguat terjadi di saat Indonesia sedang menerapkan sistem pilkadadalam penentuan kepala daerahnya di tingkat kabupaten/ kota dan tingkat provinsi. Banyak lapangan atau jabatan pemerintahan strategis yang 'ditugaskan' kepada kerabat dan/atau 'bawahan' yang dianggap telah ikut berjasa ketika proses pilkada dalam menyukseskan dirinya untuk mengurus pemerintahan agar dirinya 'sukses' dan 'aman' ketika selama dan setelah menjabat kepala daerah.

Budaya ini juga ditengarai terjadi ketika 'bos' menjadi pejabat politik, pemerintahan, dan/atau administrasi publik yang lebih tinggi daripada kepala daerah. Memang, di belahan bumi mana pun, hal ini 'biasa', tidak aneh, dantidak 'nyeleneh'. Itumungkin bisa dipahami dan 'dibenarkan' sejauh tujuan dan hasil kinerjanya lebih mengutamakan untuk kepentingan masyarakat, publik, rakyat, pemilih, bangsa, dan negara. 
Akan tetapi, hal itu menjadi tidak patut dan tidak pantas apabila lebih mengutamakan untuk kepentingan yang sebaliknya, yaitu untuk kepentingan dirinya, keluarganya, kerabatnya, kroninya, asal golongannya, asal daerahnya, asal suku bangsanya, dan/atau asal seagamanya.

Budaya statecraft governance seperti di atas menjadi sangat tidak terpuji apabila itu semua sambil melakukan korupsi uang negara dalam APBN, uang daerah dalam APBD, atau uang desa dalam APBDes.

Dengan demikian, atas dasar itu, budaya statecraft governance merupakan suatu pola perilaku yangdiperintah dalam membangun relasi sosial-pemerintahan dengan yangmemerintah, berdasarkan prinsip ingroup-out-group berdasarkan ikatankekerabatan. Oleh karena itu, ukuran in-group ini adalah ikatan sekerabat atau semacamnya, dan di luar hal itu dapat dianggap out-group, bukan kerabat, atau bukan sekerabat. Hal ini dapat dianggap sebagai cara atau strategi membangun budaya ikatan berkelompok dalam berpemerintahan agar ajeg dan harmonis.

Kelompok-kelompok dalam kategori tersebut adalah suatu ikatan berdasarkan pertalian darah atauseolah seperti pertalian darah atau semacamnya, like brotherhood in governance relationship yang dipandang mampu menguatkan ingroupnya. Artinya, keanggotaan di dalam sebuah kelompok sosial pemerintahan akan lebih ajeg bila setiap anggota memiliki ikatan-darah. Dengan demikian alur otoritas yangmemerintah dengan yang-diperintah akan harmonis sesuai dengan otoritas dan urusan pemerintahan masingmasing. Hal seperti itu, sebagai salahsatunya, berdampak pada menguatnya hubungan pemerintahan dalam sistem dan proses pemerintahan-kekerabatan (statecraft governance). Inilah suatu contoh yang dimaksud dengan sejatinya sebuah kelompok sosial dalam budaya statecraft governance.

Otoritas setiap yang-diperintah memiliki labelnya sendiri dalam bentuk atribut-atribut. Atribut tersebut mencirikan siapakah pemegang otoritas masing-masing. Adapun masing-masing pemegang otoritas tersebut dibedakan berdasarkan degree of differentiate, sesuai dengan kapasitasnya. Kapasitas setiaptingkatan akan membedakankualitasdankuantitasnya. Atribut tersebut secara kasat-mata memudahkan pemegang otoritas agar siapa pun tidak keliru dengan siapakah ia berhadapan dan bagaimanakah penghormatan yang pantas seharusnya dilakukan, baik terhadap dirinya maupun terhadap yang-memerintah atau yang-diperintahnya.

Budaya statecraft governance memberikantempattentangbagaimana suatu keadaan atau kebiasaan pemerintahan diteruskan dari satu generasi ke generasi selanjutnya. Artinya, hak dan kewajiban seseorang 
dengan atributnya akan ditradisikan, sesuai dengan kebutuhan pemerintahan.

Salah satu perbedaannya, yangmemerintah lebih banyak mengambil peran tak terlalu banyak, dan bahkan lebih banyak bersifat seremonial pemerintahan saja. Oleh karena itu, dapat dikatakan bahwa, semakin banyak yang-diperintah, akan mengokohkan power yang-memerintah, dan sekaligus membantunya menjadikan mereka juga semacam barrier bagi kenyamanan otoritas, tugas pokok, dan fungsi pemerintahannya.

\section{SIMPULAN}

Budaya statecraft di Indonesia masih memola suatu budaya corporate organization; dalam hal ini, corporate culture dapat diterjemahkan sebagai sesuatu: is a soft, holistic concept with (Hofstede, 1994:18). Artinya, pola tersebut berisi sejumlah orang yang bergiat dalam suat upemerintahan yang relatif setara dan sederajat, akan tetapi hal tersebut dipandang sama karena dianggap pekerjaan bawahan dengan derajat lebih rendah daripada atasan.
Hal di atas, dalam bahasa pemerintahan, dikenal sebagai statecraft governance, yaitu urusan yang-diperintah dianggap tidak lebih penting daripada urusan yang-memerintah. Pandangan ini menempatkan atribut dan jabatan melekat seolah menunjukkan fitrahnya. Fitrahtersebut pada akhirnya dianggap setara dengan atributnya. Bahkan, bangunan organisasi pemerintahannya adalah membangun barriers bagi yangmemerintah agar terhindar dari cela atau aib yang berasal dari yangdiperintah.

\section{DAFTAR PUSTAKA}

Fukuyama, Francis, 2015. Memperkuat Negara, Penerbit Gramedia, Freedom Institute.

Hofstede, Geert, 1994. Cultures and Organizations, Harper Collins Publishers, London.

Lewellen, Ted C., 1983. Political Anthropology, Bergin and Hadley Publishers, Inc., South Hadley, Massachusetts.

Peters, B. Guy, 2001. The Future of Governing. Second Edition: Revised. Kansas: University Press of Kansas. 